\title{
Inequalities reinforced through online and distance education in the age of COVID-19: The case of higher education in Nepal
}

\author{
Kamal Raj Devkota ${ }^{1}$
}

Accepted: 14 February 2021 / Published online: 3 March 2021

(c) UNESCO Institute for Lifelong Learning and Springer Nature B.V. 2021

\begin{abstract}
Coronavirus disease (COVID-19) has triggered serious disruption in economic, social and cultural dynamics around the globe. Higher education has also suffered undeniable challenges as a result of the pandemic, with thousands of university students all over the world experiencing displacement, disconnect and disengagement from formal learning. In the Global South, online and distance education programmes tend to be concentrated in urban centres. In Nepal, students from rural areas, low socio-economic and gendered spaces, and those with low proficiencies in English and technological skills are experiencing inequalities in access to and participation in online and distance education. This article outlines how universities' shift to online teaching and learning modes due to the COVID-19 pandemic has reinforced social inequalities in Nepal. For the study presented here, the author collected data through netnographic research methods. These included online interviews with university executives, online focus group discussions (FGDs) with university teachers and students, observation of and participation in online classes and policy conferences and reviews of online documents. The article analyses three overriding mechanisms which are reinforcing social inequalities in higher education: (1) universities' policy trajectories in shifting teaching/learning from face-to-face to online mode; (2) infrastructural limitations challenging effective implementation of online teaching/learning; and (3) a lack of strong pedagogic support for students from disadvantaged and marginalised spaces, including those with low proficiencies in English and technological skills. The author presents a number of tangible strategies for universities to implement in order to mitigate social inequalities. He recommends the adoption of policies and practices that optimise the inclusive use of online and distance education programmes for best effect, both now and in the postpandemic era.
\end{abstract}

Kamal Raj Devkota

kamalrajdevkota7@gmail.com

1 Research Centre for Educational Innovation and Development, Tribhuvan University,

Kathmandu, Nepal 
Keywords higher education · COVID-19 $\cdot$ online teaching and learning · policy trajectory $\cdot$ infrastructural limitations $\cdot$ inequality

\section{Résumé}

L'aggravation des inégalités en raison de l'éducation en ligne et à distance à l'ère de la COVID-19: le cas de l'enseignement supérieur au Népal - La COVID-19, maladie due au coronavirus, perturbe gravement la dynamique économique, sociale et culturelle aux quatre coins du globe. Avec des milliers d'étudiants universitaires du monde entier déplacés, déconnectés et désengagés de l'apprentissage formel, l'enseignement supérieur s'est vu confronté à d'indéniables difficultés provoquées par la pandémie. Dans les pays du Sud, les programmes d'éducation en ligne et à distance tendent à se concentrer dans des centres urbains. Au Népal, les étudiants des zones rurales, de communautés socio-économiques défavorisées et genrées, et qui maîtrisent mal l'anglais et l'informatique se trouvent confrontés à des inégalités quant à l'accès et la participation à l'éducation en ligne et à distance. Cet article expose brièvement comment le passage des universités à des modes d'enseignement et d'apprentissage en ligne, dû à la pandémie de COVID-19, a creusé les inégalités au Népal. Pour l'étude présentée ici, l'auteur a collecté des données selon des méthodes de recherche netnographiques, en s'appuyant, notamment, sur des interviews en ligne avec des dirigeants d'universités, sur des discussions de groupe en ligne avec des enseignants et étudiants universitaires, sur l'observation de cours et de conférences politiques en ligne - et la participation à ces cours et conférences - et sur l'analyse de documents en ligne. L'article analyse trois mécanismes prépondérants qui creusent les inégalités sociales dans le domaine de l'enseignement supérieur : (1) la démarche politique des universités concernant la transition de l'enseignement/ de l'apprentissage en face-à-face au mode en ligne ; (2) les limites infrastructurelles qui compliquent la mise en œuvre efficace de l'enseignement/de l'apprentissage en ligne ; (3) enfin, l'absence de soutien pédagogique puissant pour les étudiants de communautés défavorisées et marginalisées, y compris ceux qui maîtrisent mal l'anglais et l'informatique. L'auteur présente tout un ensemble de stratégies concrètes que les universités pourraient mettre en œuvre pour réduire les inégalités sociales. Il recommande l'adoption de politiques et de pratiques optimisant l'utilisation inclusive de programmes d'enseignement en ligne et à distance pour garantir des résultats optimaux, tant maintenant que quand la pandémie appartiendra au passé.

\section{Introduction}

In addition to the devastating number of human casualties, the rapid spread of the infectious coronavirus disease (COVID-19) has triggered a serious disruption of economic, social and cultural dynamics around the globe. The challenges and setbacks suffered by the education sector due to this ongoing pandemic ${ }^{1}$ are undeniable.

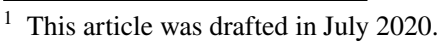


The temporary, yet indefinite, suspension of face-to-face activities of higher education institutions (HEIs) globally (UNESCO-IESALC 2020) has caused millions of students of both school and higher education to experience "displacement", "disconnect" or "disengagement" from formal learning. As elsewhere in the world, HEIs in the Global South were forced to move their courses online in their effort to maintain and facilitate teaching and learning. However, in Nepal, open and distance learning $(\mathrm{ODL})^{2}$ programmes are concentrated largely in the country's urban and suburban ${ }^{3}$ centres, even if some of the universities and their affiliated colleges in more remote, yet internet-accessible locations, have initiated attempts to include university teachers and students there too. Therefore in the absence of nationwide provision of electricity and internet connectivity, students from remote areas, low socio-economic and gendered spaces, as well as those with low proficiencies in English ${ }^{4}$ and technological skills, are experiencing social inequalities in and through ODL. This is a serious concern for higher education in Nepal, where government investment is insufficient. For example, figures published by the UNESCO Institute for Statistics shows that the education sector received only 14.1 per cent of the total budget in the fiscal year 2018 (UIS 2019). Moreover, the government expenditure on higher education was last recorded at USD 626.6 per student in the fiscal year 2015 (ibid.), which is almost not justifiable for maintaining quality education.

In this context, this article examines social inequalities reinforced by ODL, focusing on universities' practices implemented before and increased during the emergent pandemic. Obviously, Nepal has undergone significant development in terms of access to and participation in higher education since the middle of the 20th century (Bista et al. 2019; Bhatta 2015). ${ }^{5}$ However, considering the participation of students from disadvantaged, marginalised and gendered spaces in Nepalese society, it is worth investigating the extent to which the issue of equality in terms of access and quality education has been addressed (Kolbel 2013; Witenstein and Palmer 2013). Critical observations often point out that ambiguous educational policies and their nationwide implementation are resulting in social inequalities in higher education (Timsina 2016; Carney 2009). Such inequalities are manifested in and through ODL in higher education, which was not yet widely practised in pre-pandemic Nepal (Bajracharya 2014). Due to the risk of infection with COVID-19 in the conventional

\footnotetext{
${ }^{2}$ Open and distance learning (ODL) "combines aspects of two separate concepts, 'open learning' and 'distance learning' (Gaskell 2017). Open learning refers to accessible, structured learning which includes dialogue and support systems, but also learners' choice of when (e.g. at which time of day/on which day etc.) to study. Distance learning refers to learning which can be engaged in irrespective of the learner's geographical whereabouts in relation to the teacher/educational institution providing the course.

3 In this article, I use the terms urban and rural places/settings in a generic sense. Urban spaces are cities and bigger towns which have higher education colleges and offer access to modern facilities such as electricity and the internet. By contrast rural spaces refer to villages; settings where these institutions and facilities are either lacking or not well managed.

${ }^{4}$ Proficiency in English is necessary for Nepalese university students to enable them to study and understand the contents and reading materials prescribed and recommended by the faculties and subject committees. English proficiency is also necessary to enable students to use online learning tools and platforms.

5 Nepal's first university was established in 1959.
} 
mode of face-to-face teaching, universities have been forced to maintain at least some of their courses through moving instruction online. Yet, in the absence of appropriate policies and pertinent infrastructure development, most of Nepal's universities and their colleges are evidently confused and perplexed as they struggle to put this into practice, even if some of them have made attempts to engage their teachers and students through online tutorials during this pandemic.

\section{Higher education development in Nepal: pathways and labyrinths}

Even though Nepal's history of higher education is comparatively young, it developed along complex trails and labyrinths. Its breakthrough is often attributed to the establishment of Tribhuvan University in 1959 (Bhatta 2015; Gaulee 2014), although Tri Chandra and Sanskrit Colleges were founded earlier under the affiliation of Indian universities. ${ }^{6}$ This university remained the single unchallenged HEI in the nation for two and a half decades after its establishment. ${ }^{7}$ However, along with the macropolitical changes and economic shifts Nepal has grappled with during the past few decades, Nepal became fairly open to welcoming and accommodating the establishment of several more universities, and their mushrooming constituent and affiliated public and private colleges (Bista et al. 2019). Currently, Nepal has a total of 11 universities, ${ }^{8}$ along with four university-level medical academies and 1,407 university-affiliated campuses, all of which serve various tertiary education programmes throughout the nation (MoEST 2017). Besides being the oldest, Tribhuvan University is also Nepal's largest university, educating a vast majority of the country's tertiary students (Witenstein and Palmer 2013). Through its 62 constituent campuses and 1,060 affiliated colleges scattered across the country in both urban, suburban and rural locations, this university alone currently serves more than 80 per cent of the total population of higher education students enrolled across the nation (UGC 2018).

\footnotetext{
6 Tribhuvan Chandra Intermediate College (later renamed Tri Chandra college) was established in Kathmandu in 1918 and was affiliated to Patna University. Sanskrit College was established in Kathmandu in 1948 and was affiliated to Queen's College in Banaras (Varanasi). However, another Nepalese college, the College of Education (established in 1956) "awarded its own degrees on the authority of the Nepal Education Ministry" (Wood 1965, p. 51).

7 The next university to be founded was Mahendra Sanskrit University (now called Nepal Sanskrit University). It was established in 1986 as result of the Nepalese government's implementation of a multiuniversity concept initiated in 1983. All other universities were established only after multi-party democracy had been restored in 1990.

8 Among the universities, Tribhuvan University (TU), Nepal Sanskrit University (NSU), Agriculture and Forestry University (AFU), and Nepal Open University (NOU) are government-aided public universities. Purbanchal University (PU), Far Western University (FWU) and Mid-Western University (MWU) are often considered as regional universities, though they have their affiliations across the nation. Pokhara University (PU) and Kathmandu University (KU) are community-supported public universities. Lumbini Bauddha University (LBU) and Rajarshi Janak University (RJU) are also public universities. In addition, there are four university-level medical academies, all of which are autonomous: the BP Koirala Institute for Health Sciences (BPKIHS), the National Academy of Medical Sciences (NAMS), Patan Academy of Health Science (PAHS), and Karnali Academy of Health Sciences (KAHS).
} 
Developing and expanding the provision of higher education has often been understood as a key mechanism for fostering the modernisation and development of Nepal. Elsewhere (Devkota 2019), I have critically described how five ideological forces shaped the development phases of modern education in Nepal in general. These forces were (1) Rana elitist; (2) developmentalist [bikasi]; (3) monarch-led panchayat; (4) neoliberal; and (5) neoliberal-globalist. Rana refers to an aristocratic dynasty who seized state power and ruled the Kingdom of Nepal from 1846 until 1951. Rana elitist ideology restricted education to the Rana rulers and their courtiers, denying access to the general public because they thought that formal education would raise public consciousness which might then challenge their sovereignty of the nation. The Nepali word bikas refers to development. Bikasi (developmentalist) ideology considers those educated through modern schooling as "developed", "advanced" and "civilised", and the rest as "underdeveloped" (Shrestha 1997). The Hindi word panchayat refers to a village council. Monarch-led panchayat ideology promoted education as a key to modernisation and development, yet a large section of Nepali citizens still remained out of school due to deep-seated caste, class and gender discrimination. Neoliberal ideology promoted marketisation, deregulation and reduction in government spending. Finally, neoliberal-globalist ideology for the last few decades has promoted globalisation and marketisation effects in education. These ideological forces have informed higher education policies and pedagogies in different, yet historically situated, chronological phases of national development.

In their editorial to a special issue on "Education reform in Nepal: From modernity to conflict", Stephen Carney and Jeremy Rappleye (2011) highlight the effects of three overriding tenets of neoliberalism - marketisation, privatisation and decentralisation. On the theoretical base of these tenets, Kapil Dev Regmi points out how "the hegemonic assumptions of neoliberalism perpetuated deeply into education policies and plans" (Regmi 2016, p. 12) in Nepal. In another article, Regmi (2019) applies critical policy sociology ${ }^{9}$ as a methodological tool to examine the involvement of the World Bank (WB) in higher education in Nepal, arguing that WB had exerted a strong influence on Nepal's higher education policies and practices through the policy agenda of reforms, performance and competition constituted under the guise of neoliberal instrumentalism. ${ }^{10}$ However, these WB-driven policy endeavours have hardly been conducive to solving Nepal's problems such as poverty, social inequity and inequality, integration and brain drain. The result has led the graduates educated at (public) universities to experience difficulties in identifying potential future pathways despite their parents and society attaching more values and expectations to university education (Kolbel 2013). ${ }^{11}$ Behind all these

\footnotetext{
${ }_{9}$ Critical policy sociology refers to an approach of examining educational policies against how macrolevel political-economic drivers shape meso-level (institutional) and micro-level policies, policy enactments, engagement and experiences (Tomlinson 2017; Regmi 2019).

10 Instead of considering students' personal empowerment, their intellectual growth and their own goals, neoliberal instrumentalism argues that graduates will be useful for improving a country's economic performance.

11 The number of students and graduates who leave Nepal because they do not see a future for themselves has been growing in recent decades (Mainali 2019).
} 
criticisms, Nepal's higher education is constantly occupied with social selection and elite and middle-class favouritism under the patronage of social, cultural, economic and politico-ideological structures.

These structural constraints remain decisive in shaping the access of women, Dalits, $^{12}$ and diverse Indigenous peoples, including Madhesis, ${ }^{13}$ to and their participation in education in general, and in higher education in particular. The socio-historically informed "patriarchal construction of gender roles" has persistently prevented women from accessing quality modern education (Devkota 2019). Equally, socioculturally informed caste hierarchy has pushed a heterogeneous group of Dalits into an ongoing experience of discrimination in social, cultural, religious, economic as well as educational domains (Cameron 2007). Madhesis and linguistic minorities ${ }^{14}$ also continue to experience different kinds of social inequalities due to their ethnic and regional backgrounds, even long after the introduction of mass schooling in the early 1950s. ${ }^{15}$ These pre-existing social inequalities based on caste, class, gender, ethnicity, regionality and linguistic background are now being reinforced through online and distance modes of teaching and learning, since members of these social groups are still experiencing disconnect and disengagement from higher education due to their lack of required physical infrastructure such as internet access, computers and mobile phones, as well as the absence of a strong student support system at the respective colleges located in rural settings.

\section{Online and distance education: emerging practices in higher education}

Over the past 2-3 decades, online teaching and learning practices have been increasingly embraced in HEIs and colleges of the Global North (Dumford and Miller 2018; Hennrie et al. 2015; Kim and Bonk 2006). ODL provides educational opportunities to individuals who often wish to continue their postsecondary education, yet

\footnotetext{
12 Dalit [derived from Sanskrit dalita $=$ oppressed] is a politico-ideologically constructed term to refer to heterogeneous groups of people mostly belonging to the lowest caste, i.e. "untouchables", in the classical Hindu caste system. After the establishment of democracy in 1951, Nepal's successive constitutions (adopted in 1959, 1962, 1990, 2007 and 2015) have all abolished social discrimination based on caste and untouchability. However, despite some significant changes, caste discrimination is still prevalent in Nepalese society and continues to shape the social, cultural, economic and religious life of Dalit people.

13 In Nepal, the term "Madhesi" [probably derived from Sanskrit madhya desh = middle country] often draws political and ideological debate with reference to identity, ethnolinguistic vitality and inclusivity. However, in this article, it serves to indicate the citizens living in the Southern flatlands (also called Madhes or Tarai) of Nepal near the Indian border. It is worth noting that there are diverse ethnic groups such as Tharus, Tarai Dalits and Janajatis who live in the Madhes, yet do not consider themselves as Madhesis.

14 The number of languages currently spoken in Nepal is estimated to be at least 123, probably more (Fillmore 2019).

15 Under the reign of the Rana dynasty (1846-1951) education was an elite prerogative, while the general public was denied access to schooling. Mass schooling was introduced after 1950, and today education from grade 1 at entry primary level to grade 8 at the end of lower secondary level is compulsory and free of charge.
} 
experience geographical, temporal, social, cultural and other constraints to attending face-to-face classes (Crawford-Ferre and Wiest 2012). However, universities and colleges in developing countries in the Global South are still lagging behind. Than Nwe Aung and Soe Soe Khaing point out a number of challenges related to ICT infrastructure, the nature of the course, contextual factors, instructors' competencies, e-readiness, ${ }^{16}$ etc. that universities and colleges encounter while implementing online teaching and learning (Aung and Khaing 2016, pp. 407-409). Shailendra Palvia et al. (2018) broadly examine how country factors (ICT capacity, internet diffusion, etc.), institutional culture (public versus private, profit versus non-profit, etc.) and curricular factors (graduate or undergraduate, fully online versus blended learning, etc.), as well as micro-level factors (teacher, teaching mode, etc.) affect the implementation of ODL (ibid., p. 235). These factors often play a decisive role in shaping the status, challenges and opportunities of online and distance teaching and learning in tertiary education in developing nations like Nepal.

The first initiation of ODL in Nepalese tertiary education can be traced back to the College of Education, which began offering adult education through radio broadcasts in 1958. Later, the Ministry of Education (MoE) initiated a Radio Education Teacher Training Project (RETTP) in the late 1970s and 1980s with the technical and financial support of the United States Agency for International Development. (USAID) and the United Nations Children's Fund (UNICEF) (Holmes 1990). However, it was not until the Nepalese government pledged its commitment by signing a cooperation proposal set up by the South Asian Association for Regional Co-operation (SAARC) Consortium to Open and Distance Learning (SACODiL) in 1999 that discussing and conceptualising its own open university in Nepal became possible. And even after that, the process took more than one and a half decades. Despite a number of proposals, ${ }^{17}$ initiatives and dialogues (Dhakal et al. 2010), the concept was not in fact formalised until the government of Nepal passed an Act (GoN 2016) establishing Nepal Open University (NOU) in 2016. By this time, Tribhuvan University (TU) and Kathmandu University (KU), had already established their own ODL programmes and offered a few programmes for Bachelor and Master's degrees in Education and Social Sciences (Pangeni 2016).

These ODL-based higher education programmes, whether through TU (by establishing its Open and Distance Education Centre), ${ }^{18} \mathrm{KU}$ or NOU itself, have provided (in principle) access to higher education for those people who cannot attend conventional classes in face-to-face mode due to geographical, temporal,

\footnotetext{
16 E-readiness refers to the preparedness of institutions, university teachers and students to accept and be equipped with technological infrastructure for online learning.

17 The Non-Resident Nepali Association (NRNA) of expatriates, in alliance with the Canada Foundation for Nepal (CFFN) organised a conference in 2010, and offered its support for the establishment of an Open University of Nepal for providing higher education to rural and otherwise marginalised people.

18 The Open and Distance Education Centre (ODEC, TU) was established in 2015 as a constituent independent academic organisation of Tribhuvan University, and aims to provide access to quality higher education through ODL modules. It has run academic programmes in Mathematics and English education and is planning to initiate other programmes as well. For more information, visit https://odectu.edu. $\mathrm{np} /$.
} 
work-related, cultural and/or other constraints. Yet, with the exception of a few NOU programmes, ${ }^{19}$ most of the ODL programmes offered by the aforementioned universities were in fact only delivering their service to a limited number of students. Challenges remained in terms of the educultural regime still requiring attendance in face-to-face classrooms for higher education degrees, the understanding of ODL as a secondary learning space, and the definition and understanding ODL policymaking, curriculum design and classroom delivery in and through the same monolithic framework of higher education.

However, with the onset of the COVID-19 pandemic, online teaching and learning - accelerated suddenly - has become an emerging practice in Nepalese higher education. Conventional face-to-face tutorials in HEIs have shifted to online teaching and learning in major urban cities. University colleges have enjoined their teachers and students to get connected through various internet-mediated online platforms. Of course, the students who have benefitted are those who live in urban spaces and have better access to digital equipment and internet have benefitted than their rural peers. However, the attempts of universities and colleges to run teaching and learning online does raise concerns in terms of equality, quality, uniformity and validity. While acknowledging the growing relevance of ODL in higher education in the face of society's increased interaction with sophisticated means of communication and technology, there are serious drawbacks, violating the educational rights of disadvantaged students. The overarching question guiding this article is how the sudden and in many cases unplanned move of universities and colleges to ODL is reinforcing social inequalities in Nepal which already existed before the onset of the COVID-19 pandemic.

\section{Research questions}

Based on this overarching question, the research questions guiding this study were:

- What policy gaps are Nepalese universities encountering in their move from face-to-face to online and distance teaching and learning?

- How do infrastructural limitations challenge the effective implementation of online and distance teaching and learning in Nepalese universities?

- How does a lack of strong pedagogic support reinforce social inequalities among students who come from socio-economically marginalised and peripheral backgrounds, and seek "a better life" in and through higher education?

\footnotetext{
19 NOU has run MPhil, Master's, and Diploma-level academic programmes in Education, Management and Social Sciences through distance online learning mode, and has also planned to extend Science, Technical and Vocational programmes.
} 


\section{Methods and analytical framework}

As a lecturer at Tribhuvan University's Research Centre for Educational Innovation and Development (CERID), my research interest lies in investigating progress in making higher education accessible to all Nepalese students, irrespective of their gender, their caste, their faith, their socio-economic background or their location. My purpose is to find out where and what their needs are, so that these can then be addressed effectively in terms of policies and strategies.

I began my fieldwork for this research into inequalities of access to and participation in ODL in December 2019 and continued until May 2020, i.e. after COVID-19 had triggered a complete closure of HEIs in Nepal. ${ }^{20}$ Considering the use of "online archives and internet communications as [my] main field sit[e]" (Kozinets 2015, p. 3), I chose a netnographic ${ }^{21}$ approach (Kozinets 2010; Bowler 2010; KulavuzOnal 2015) to data collection and analysis for this study. Among the multiple methods I used were: (1) online interviewing (O'Connor and Madge 2017) with policymakers, university executives, teachers and students to explore their perspectives and experience of online teaching; (2) online focus group discussions (Abrams and Gaiser 2017) with teachers and students of urban spaces using online platforms such as Zoom, Microsoft Teams, etc.; and (3) phone interviews (Block and Erskine 2012) with campus authorities, teachers and students of rural settings. Telephone interviews were necessary to reach the higher education population in rural areas where internet connectivity was poor. I complemented these three methods with (4) observation of online classes, policy dialogues and workshops, and a review of online materials such as texts, audio and video recordings, etc..

\section{Interviews and focus group discussions}

A total of 98 participants (37 female, 61 male), ${ }^{22}$ who fall into four groups, were involved in the interview and focus group discussions I conducted for this study. The first group included 10 officials (vice-chancellors of two universities, rectors of two other universities, a member of Nepal's University Grants Commission (UGC), and five university educators who were involved in higher education policymaking bodies including the High Level National Education Commission - 2019). I interviewed

\footnotetext{
20 Though Nepal's first case of COVID-19 presented on 13 January 2020 (Bastola et al. 2020), it was not until 19 March that nationwide closures of educational institutions were implemented to curb the spread of the virus (Radhakrishnan-Nair et al. 2020), following the World Health Organization's assessment of the outbreak as having reached pandemic status on 11 March 2020 (WHO 2020).

${ }^{21}$ Coined by Robert V. Kozinets (2010), the term netnography refers to a methodological approach to data collection which includes the use of internet-mediated online interviews and focus group discussions (FGDs), resulting in the collection of rich samples of multifarious communicative acts and interactions in the form of textual, graphic, audio, photographic and audio-visual expression.

22 My study received research approval and official permission from the concerned authorities, faculties and students engaged in teaching and learning at universities and colleges. Before conducting the interviews/focus group discussions, I informed all participants of the research purpose, research process, and the security and usage of their personal details (as well as sending them formal research application documents). As required by research ethics, I obtained consent from all participants.
} 
each of these officials online in order to explore higher education policies and practice, including any short-term policies developed to address higher education issues during the COVID-19 pandemic.

Another group of participants were 14 campus chiefs representing different constituent, public and private campuses affiliated to different Nepalese universities, including TU, and located in different ecological belts of the nation. ${ }^{23}$ I interviewed these campus chiefs online in order to explore how these campuses were experiencing, and taking action locally to deal with, the challenge of maintaining courses during the pandemic.

A third group of participants were five groups of teachers $(n=20)$, and six groups of students $(n=23)$ representing, constituent, public and private campuses located at different geographical regions. With these participants, I conducted online focus group discussions (online FGDs) in order to explore how they were navigating the online learning space which was more prevalent in urban and internet-connected cities and towns during the emergence of COVID-19.

Finally, my fourth group of participants were 24 students and 7 teachers who lived in the remote areas of Nepal's eastern hills, western hills and mountainous region. Since they had hardly any internet access, I conducted telephone interviews with this last group.

Online interviews and online group discussions lasted between half an hour and one hour, whereas telephone interviews lasted 10 to 15 minutes each. These semistructured interviews and focus group discussions were held in Nepali. With participants' permission, I recorded them and later transcribed and translated them into English.

\section{Observation and review}

Besides these interviewing methods, I used observation in diverse online spaces including online classrooms, policy dialogues and online workshops that used Zoom, GoogleMeet, Microsoft Teams, etc. ${ }^{24}$ Using these online platforms enabled me to engage as a netnographer in observing multi-site online communities of policymakers, authorities, educators, teachers and students (Kulavuz-Onal and Vasquez 2013) and exploring multifarious perceptions, senses, experiences, communicative acts and interactions (Kozinets 2010) occurring in these virtual spaces. For example, I observed and participated myself in three online policy dialogues and meetings where university executives, including representatives of the Ministry of Education, Science and Technology (MoEST), focused their discussion on how they could best

\footnotetext{
23 In terms of its topography, Nepal has three ecological belts, ranging from the Terai plains (average elevation below $750 \mathrm{~m}$ ) to the High Himalaya mountains (average elevation from 4,000 to above $8,000 \mathrm{~m})$.

${ }^{24}$ In each case, I requested permission to be admitted, providing details about my study and explaining its purpose. First, the concerned faculties in the case of online classes, and the organisers in the case of online workshops and dialogues, discussed in their own forums. Then, in each case, the concerned official sent me their schedules and links with their consent to allow me to participate and explore on my research issue.
} 
handle issues of discontinued instruction during the COVID-19 pandemic. Equally, I observed three online workshops organised by two central departments of TU for both students and teaching staff, and two further online workshops for teachers of TU and Mid-Western University (MWU).

Obtaining consent from the concerned university departments, campuses and teachers, I also observed eleven online Master's-level classes in Education, Management, Science, and Humanities and Social Sciences mostly taught at TU central departments and affiliated campuses located in different geographical regions, and also a few classes of MWU and Pokhara University (PU). I collected information regarding perception, experience, participation and action of university teachers and students.

Alongside, I collected a large number of online texts, audios, videos and communicative events concerning higher education issues during the COVID-19 pandemic, as well as relevant information disseminated through different media including newspapers, e-papers, online portals, TV channels, YouTube, Facebook, etc. (Kozinets 2015, p. 3). I investigated such internet-mediated data for an extended period of time, extracting key narratives and texts spoken or written by higher education stakeholders including executives, university teachers and students.

\section{Analytical framework}

Over time and as a whole, the body of data I had collected comprised interview transcripts, reflexive field notes generated through multi-site observation, internet-mediated textual, graphical, photographic, audio-visual, and screen-captured social media material particularly related to higher education and online teaching and learning in Nepal. As mentioned earlier, I opted for netnographic analysis (Kozinets et al. 2014) because it is best suited for evaluating the kind of qualitative data I had collected. Using ATLAS.ti, ${ }^{25}$ data analysis, I proceeded through open coding, categorising and developing themes (Corbin and Strauss 2015) in the light of netnographic sensibility (Reid and Duffy 2018). ${ }^{26}$ My research questions guided me in categorising the codes into three categories: (1) policy; (2) infrastructural preparedness; and (3) experience in online teaching and learning.

The first category, policy, comprised existing higher education policies on online and distance teaching and learning; policy gaps; university perspectives on online instruction; and short-term policies to address instructional issues during COVID19. The second category, infrastructural preparedness, comprised current infrastructure; curricular constraints; students' and teachers' ICT knowledge and access;

\footnotetext{
25 ATLAS.ti is a software tool for the analysis of qualitative data (especially textual data), enabling researchers to apply codes to collections of unstructured texts and internet-mediated data including photos, videos and chats.

${ }^{26}$ Netnographic sensibility, according to Emma Reid and Kathering Duffy, refers to the analysis of "large data sets of social media ... through bridging the divide between the small, rich and contextually nuanced data that is the hallmark of netnography and the scope and scale of data made possible through social media listening conventions" (Reid and Duffy 2018, p. 263).
} 
students' and teachers' internet access, etc. Finally, the third category, experience in online teaching and learning, comprised university teachers' and students' attitude towards online instruction; challenges for attending online classes; socio-economic constraints; info-techno literacies; gender, class and caste characteristics and (dis) engagement in online classrooms; the presence/absence of a student support system, etc.

From the analysis as such, three intersecting themes emerged: (1) policy trajectories of online teaching and learning in higher education, (2) limitation of infrastructure required for the effective implementation of ODL, and (3) experience of teachers and students across macro- and micro- structures, in combination with a lack of strong student support. Amidst a complex intersectionality of these themes, my findings seem to confirm that social inequality is being reinforced through online and distance education in higher education in Nepal, especially in the context of short-term policies introduced in the face of the COVID-19 pandemic.

\section{Policy trajectories of online and distance teaching and learning}

In the 15th Five-Year Development Plan (2019-2024) of the National Planning Commission (NPC), the Government of Nepal has formulated its strategy to improve and expand the Open and Distance Education System in order to provide access to higher education to people in remote settings, and those who are in need of alternative pathways to higher education (NPC 2020, p. 176). Similarly, the University Grant Commission (UCG) has formulated its strategies (8.1) to promote access to open and distance education retaining trustworthiness and competitiveness; and (8.2) to provide access to higher education to those from rural settings, women, Indigenous groups, Dalits, Madhesis, citizens with disabilities, and people from economically disadvantaged communities (UGC 2015, p. 7). In principle, these national policies and strategies are supposed to provide a framework for designing and implementing any kind of academic programme in universities and colleges. However, most of the educators I interviewed for my study remarked that the "same policy guideline" which was designed to frame conventional face-to-face teaching has been found to be an "inflexible guideline" for designing and implementing ODL at different universities. Such "a monolithic ritual" for framing higher education policies is seen as a key obstruction, resulting in the failure of expected development of ODL in Nepal. A teacher educator of a public university commented:

The two modes [face-to-face and online and distance] of teaching and learning do have the same process of curriculum designing, content selection and even methods of assessment; they differ only in the mode of classroom delivery, i.e. face-to-face and internet-mediated, otherwise there is no fundamental difference between them, and it may not lead to the proper development of ODL as expected. (Online interview)

ODL programmes were principally initiated to provide access to higher education to those who could not attend face-to-face classrooms. TU, KU and NOU have initiated ODL programmes in order to meet this objective. However, their programmes 
remain out of reach for many students who live in remote places and aspire to individual progress through access to and participation in higher education. As many of the educators among my respondents remarked, the aim behind initiating ODL seriously contrasts with policy enactments. Since policy implementation remains centralised, it still defies the autonomy and decentralisation of the affiliated colleges and institutions in implementing their localised policies and programmes in a manner which is adjusted to the needs of the student communities they serve. This is the true cause behind universities' inability to run ODL courses with a realistic potential to reach the targeted population during the COVID-19 pandemic.

Theoretically, the Second Higher Education Project (2007-2014) and the Nepal Higher Education Reform Project (2016-2020) were/are supposed to promote decentralisation and autonomy of university campuses/colleges across the nation. However, the centrally lavished policies based on WB-funded Higher Education projects, including the current Higher Education Reforms Project (HERP), are still prominently decisive in all ways of regulating the academic programmes, thus overriding national reform projects and strategic guidelines. Most of the teachers I interviewed sensed this as a crucial challenge for motivating and engaging local actors in policy formulation and implementation. A teacher educator of a public university remarked,

The lack of a participatory approach in higher education policy formulation has resulted in a weak institutionalisation of the policy terms, which has in turn pushed universities and local colleges into not being fully prepared for handling the effects of the current COVID-19 pandemic through ODL programmes. (Online interview)

My analysis of interviews and online interactions of university executives, policymakers, campus chiefs, university teachers and students revealed that the need for ODL increased remarkably with the temporary closure of HEIs for an indefinite period of time. With the ongoing pandemic in mind, TU and KU, as well as some other universities, initiated transitional policies for continuing teaching and learning through online means. These universities urged their affiliated campuses/colleges to initiate online teaching and learning using diverse online platforms. However, this sudden shift to online tutoring was and continues to be limited to urban areas. Large numbers of university teachers and students, particularly those living in rural villages, were and continue to be disconnected from learning.

\section{Infrastructural limitations}

David Bloom and Henry Rosovsky argue that under the influence of current globalisation changes, most of the developing nations have become buffer zones of powerful forces including democratisation, rapid demographic change, knowledge and information, and technological revolutions (Bloom and Rosovsky 2007 , p. 444). Under the influence of these forces, higher education has become a "global commodity" within and across nations (Naidoo 2007). Access to higher education has become a public demand in nations like Nepal, which has 
accommodated a tremendous expansion of HEIs within the space of only a few decades, either through establishing new universities or through the affiliation of mushrooming public and private colleges with pre-existing universities (Bista et al. 2019; Bhatta 2015). However, most of these institutions seriously lack the infrastructure required to operate effectively. Underfinancing is crucially affecting not only the infrastructural development of Nepalese HEIs but also the quality of teaching, learning and research they are delivering (Bhatta 2015). My respondents, particularly the campus chiefs and teachers of constituent and affiliated campuses, explained how their institutions lacked basic facilities such as a proper and reliable supply of electricity, internet connectivity, access to an e-library, and ICT laboratories for teachers and students. Most of the participant campus chiefs and teachers of campuses/colleges in rural settings reported that the emergence of the COVID-19 pandemic had disconnected them from the continuation of teaching and learning activities. A chief of a TU-affiliated campus located in Nepal's eastern hills region explained the condition of infrastructural limitation in these terms:

It is really difficult for us to run online classes, we face unstable electricity and "almost no" internet connectivity; moreover, most of our students do not have laptops and smartphones since they are mostly from economically disadvantaged communities. Since the lockdown we and our students are completely disconnected from formal teaching and learning. (Phone interview)

Similarly, another campus chief working at an affiliated college of MWU explained:

Yes, it may be a fashion in the urban areas where there is a good internet access, no power-cuts at all, and for those who have digital devices, but not for us. Truly speaking, for us, it seems like "äkäshko phal änkha tari mar" [if the sky falls, we will catch the larks] because we don't have internet access, electricity is hardly available and hardly any of our students have computers or smartphones. (Online FGD)

By contrast, university teachers and students from urban areas often explained how they experienced "the new learning and sharing platform in this digitalised world". Many of them reported how they had benefitted from diverse online classes and e-conferences through Zoom and Microsoft Teams. However, many other students - particularly those aspiring to and navigating higher education from geographically remote locations or economically marginalised communities - reported how they were facing "a complicated time" since they did not have personal computers or required digital devices or access to the internet, to an e-library or a virtual learning space. 


\section{Experiencing online teaching and learning: the lack of strong student support}

The success of ODL in higher education is measured through the relevance of instructional design and student learning, effective delivery of instructional information, adequate support provided to students, and high-quality participation and engagement of teachers and students in online classrooms (Bao 2020; Dumford and Miller 2018). However, in the presence of a strong policy gap, combined with a lack of required infrastructure at societal, institutional and individual levels, scoring well on these indicators is quite challenging in developing nations such as Nepal.

Focusing on the last of these indicators, participation and engagement of teachers and students in online and distance teaching and learning, in the context of COVID-19, the analysis of my interviews, online classroom observations, and online discourses of teachers and students of different universities throughout Nepal highlighted the particular importance of three factors. These factors are (1) access; (2) quality participation; and (3) validity, All three are deeply intermingled both with macro structures (such as gender, poverty, geographical background, accessibility of physical infrastructures, etc.), and micro structures (such as for low proficiencies in English and technological skills, availability of internet, personal computers and construction of learning space, etc.).

In terms of "access", most of the students studying at urban HEIs responded that they had some kind of regular access to online classes. In terms of "quality participation", the online classroom conversations they participated in or on Facebook walls provided some explicit and implicit evidence of their attitude to and engagement in online learning. In terms of "validity", they were provided with a platform to engage themselves in online forums, e-conferences and e-seminars, and were also given opportunities to explore content areas of their university courses. Nonetheless, the students studying science and technical subjects did not unreservedly feel that they had quality participation online, since this mode of delivery did not integrate a major component of their course, namely the heavy lab work they were required to do which could only be conducted in the university and college labs.

A significant number of responding students enrolled at less urban HEIs reported having only irregular access to online classes, enabling them to be only partially engaged, until they tried using internet data packages. ${ }^{27}$ Yet, even this attempt resulted in far from high quality participation, and therefore very poor validity. Many other students had practically no access to online classes. They were entirely detached and disconnected either because they had no internet connection at all, or because they could not buy data packs on a regular basis. Others did not have computers and/or smart phones of their own in order to get connected. A male student studying for a Master's degree in English education at a public college narrated his efforts and frustrations in trying to attend online classes as follows:

\footnotetext{
27 Internet data packages enable students (or other users) to get internet access for the duration and gigabytes they pay for. Service providers, such as Nepal Telecom, offered various plans and prices. Some plans such as e-Shikshyalaya Packs and Happy Learning Packs, for example, were targeted to students.
} 
Just for getting connected to three online classes per week, I am living in a rented room [in a small town in a hill district in Western Nepal], I buy data packs and connect myself to the online class of my college. However, the internet access is not good, there are many disruptions, the video and sound of my teachers often get blurred and interrupted, it is boring and I think it [online tutoring] does not work for students like me. (Phone interview)

In a similar tone, a female student studying for a Master's degree in social sciences at a public college located in Nepal's far-western hills region explained her experience as follows:

For me, it [online class] is not possible; those who are in villages cannot attend this class. I do not have internet access ... frequent power-cuts are another problem, I tried using a data pack, but it does not work either, and we don't have money to buy data packs all the time ... As we are women and now at home, we have some household duties as well. Those who are in cities may be enjoying online classes, but in our case it is not easy, and not practical. (Phone interview)

Another female student from a Dalit background who had recently joined a Master's degree programme in the subject of sociology in a university campus in Kathmandu explicitly expressed the complexity of her challenges:

I would attend the class in the morning shift, and would work as a contract teacher in a private boarding school [in the afternoon]. Due to Corona health regulations, the school stopped operating and we were told that the school would no longer be able to pay [staff salaries]. I returned to my home village, which was challenging as it was already locked down, and I am not sure whether I will be able to come back to Kathmandu because it is difficult to find a job due to school closures. I cannot continue my studies if I don't get a job, my parents cannot pay for my studies at this age. I have to be dependent on myself ... our online class is not so systematic either; I encounter so many interruptions as I try to connect using the student data pack ... it is quite complicated, these days I don't attend anymore. (Online interview)

Like the participants cited above, many students noted how physical facilities were crucial in shaping their high-quality participation and engagement in online classes. Equally, responses confirmed that geographical background, economic circumstances, sociocultural construction of gendered space and household liabilities deeply intersect with the opportunity to participate in online classes. On top of challenges and disadvantages on these fronts, many students also responded that they could not engage themselves well in ODL because of their limited proficiencies in English and technological skills. One such student noted:

I am not good at English, nor at technology either, I know I could participate well if I had good English communication skills and manageable knowledge in modern technologies. Very often I get lost in my class, I can just connect to Zoom now. (Online FGD) 
Campus chiefs and teachers in rural settings explained that students struggling with social, cultural, economic and familial constrictions tend to enrol in rural campuses, while students from richer and better backgrounds go to cities. A teacher working in a rural campus explained:

Students such as married women, Dalits and the economically marginalised, or those who have jobs and cannot go to the colleges of urban cities enrol here.

(Phone interview)

In their diverse online debates and discussions on the issue of higher education access, teacher educators, university teachers and students often pointed out the absence of "a strong pedagogic support system" to students at societal, university and individual campus levels. In the absence of such support, students from economically marginalised sections of society are likely to feel disconnected and disengaged from learning during and post-COVID-19.

\section{Discussion and conclusion}

Ideally speaking, "higher education should actively seek to address social inequality and promote equity and social justice" (Mbati 2019, p. 254). It is expected to enable individuals to develop potential and capabilities by synergising national, societal and individual goals of education (Morley et al. 2009). However, far from this ideal consideration, social inequalities affecting choice, participation and engagement continue to exist in higher education based on class, race, gender, socio-economic, ethno-linguistic, and regional backgrounds (Witenstein and Palmer 2013; Morley et al. 2009; Bhatta et al. 2008).

The social inequalities experienced by the students who participated in the study presented above are not just evident in Nepalese higher education where formal education itself has long been a site of conflict (Pherali 2011), a matter of social exclusion (Devkota 2018; Valentin 2011), and a fractured space where Nepalese youth navigate their self amid instability and radical uncertainty (Madsen and Carney 2011). However, as argued by Regmi (2016, 2019), higher education policies constituted in Nepal in and after 1990s are predominantly supported by WB, and are more targeted towards buttressing neoliberal ideas of market, performance and competition. This, in turn, has resulted in higher education becoming increasingly unresponsive to the needs and aspirations of Nepalese communities and society. Amidst these arguments, the critical issue this article addresses is how pre-existing social inequalities and injustices have been reinforced through online teaching and learning in higher education in the age of COVID-19.

The above analysis of the narratives of higher education authorities, university teachers, students and all concerned revealed that most of the students from rural settings in Nepal got "disconnected" from formal learning during the time of the pandemic. Other students got "displaced" from the formal learning space after leaving for their remote home villages due to closure of their HEI. Still other students got "disengaged" from formal learning due to the lack of necessary physical facilities. By contrast, students living in urban environments had access to the internet, 
already owned the required digital devices, and also had English and technological skills, all of which enabled them to get connected to ODL offerings provided by the universities and departments.

Students lacking all these assets were left behind, experiencing online teaching and learning as unreachable for them: "äkäshko phal, änkha tari mar" [If the sky falls, we will catch the larks]. This study found most students from economically disadvantaged as well as socially and culturally marginalised social groups, including women and Dalits, and also those having low proficiencies in English and technological skills, to be disconnected and disengaged from online tutoring. In the course of the analysis described above, three intersecting issues emerged, namely (1) policy trajectories of ODL in higher education; (2) infrastructural limitation; and (3) the lack of strong student support particularly to those of marginalised and disadvantaged communities. All three factors have reinforced social inequality through the construction of a "digital divide" (Hill and Lawton 2018) among Nepalese HEIs, university teachers and students. While HEIs should focus "their efforts on technological solutions" to maintain continuity in teaching and learning (UNESCOIESALC 2020, p. 15), it is equally important that transitional policies and implementation address "the right to higher education for all within a framework of equal opportunities and non-discrimination" (ibid., p. 7).

In conclusion, ODL is an emerging teaching and learning mode in higher education in Nepal. The outbreak of COVID-19 and subsequent lockdown have amplified and accelerated the demand for online teaching and learning. Nepalese universities and colleges have been forced to adopt it as the solution for the continuation of teaching and learning. HEIs located in urban environments have made some attempts to continue their programmes through online tutoring. Most students located in urban settings are at least navigating online and digital spaces of learning. However, students with social, cultural, geographical and economic constraints, including those with low proficiencies in English and technological skills, are experiencing disconnect and disengagement. Therefore, the crucial challenge for higher education in Nepal is to reduce social inequality and prevent its reinforcement through the uneven and unequal delivery of online teaching and learning. To combat this challenge, policies and strategies need to be formulated through participatory and engaged policymaking processes in order to encourage individual colleges to explore what solutions would best fit their respective contexts to enable continuation of their teaching and learning activities. Infrastructural development and strong pedagogic support to economically, culturally and socially marginalised students, in collaboration with government, university and community efforts, need to be harnessed effectively to prevent further reinforcement of the "digital divide" in Nepalese higher education.

\section{References}

Abrams, K.M., \& Gaiser, T.J. (2017). Online focus groups. In N.G. Fielding, R M. Lee, \& G. Blank (Eds), The SAGE handbook of online research methods (pp. 435-450). London: SAGE Publications. 
Aung, T.N., \& Khaing, S.S. (2016). Challenges of implementing e-learning in developing countries: A review. In T. Zin, J.W. Lin, P. Tin, \& M. Yokota (Eds), Genetic and evolutionary computing. Proceedings of the Ninth International Conference on Genetic and Evolutionary Computing (GEC 2015), held 26-28 August 2015 in Yangon, Myanmar. Volume II. Advances in intelligent systems and computing, vol. 388 (pp. 405-411). Springer International Publishing Switzerland. https://doi.org/10.1007/978-3-319-23207-2_41.

Bajracharya, J.R. (2014). Entanglement of higher education and strength of open and distance learning in Nepal. American Journal of Educational Research, 2(11), 1091-1093. https://doi. org/10.12691/education-2-11-14.

Bao, W. (2020). COVID-19 and online teaching in higher education: A case-study of Peking University. Wiley. https://doi.org/10.1002/hbe2.191.

Bastola, A., Ranjit, S, Rodriguez-Morales. A.J., Kumar Lal, B., Jha, R., Ojha, H.C, Shrestha, B., Chu, D.K.W, Poon, L.L.M., Costello, A., Morita, K., \& Pandey, B.D. (2020). The first 2019 novel coronavirus case in Nepal. The Lancet, 20(3), 279-280. https://doi.org/10.1016/S1473 $-3099(20) 30067-0$.

Bhatta, P. (2015). Privatization through affiliation: Trajectories of higher education expansion in post1990 Nepal. Studies in Nepali History and Society, 20(2), 303-333.

Bhatta, P., Adhikari, L., Thada, M., \& Rai, R. (2008). Structures of denial: Student representation in Nepal's higher education. Studies in Nepali History and Society, 13(2), 235-263.

Bista, K., Sharma, S., \& Raby, R. L. (2019). Telling stories, generating perspectives: Local-global dynamics in Nepalese higher education. In K. Bista, S. Sharma, \& R.L. Raby (Eds), Higher education in Nepal: Perspectives and policies (pp. 3-22). London: Routledge.

Block, E.S., \& Erskine, L. (2012). Interviewing by telephone: Specific considerations, opportunities, and challenges. International Journal of Qualitative Methods, 11(4), 427-445. https://doi. org/10.1177/160940691201100409.

Bloom, D.E., \& Rosovsky, H. (2007). Higher education in developing countries. In J. J. Altbach (Ed.), International handbook of higher education (pp. 443-495). Dordrecht: Springer. https://doi. org/10.1007/978-1-4020-4012-2_22.

Bowler, G.M. (2010). Netnography: A method specifically designed to study cultures and communities online. The Qualitative Report, 15(5), 1270-1275. Retrieved from https://nsuworks.nova. edu/tqr/vol15/iss5/13.

Cameron, M.M. (2007). Considering Dalits and political identity in imagining a new Nepal. Himalaya, 27(1), 13-26. https://digitalcommons.macalester.edu/himalaya/vol27/iss 1/4.

Carney, S. (2009). Negotiating policy in an age of globalization: Exploring educational "policyscapes" in Denmark, Nepal and China. Comparative Education Review, 53(1), 63-88. https://doi. org/10.1086/593152.

Carney, S., \& Rappleye, J. (2011). Education reform in Nepal: From modernity to conflict. Globalisation, Societies and Education, 9(1), 1-9. https://doi.org/10.1080/14767724.2010.513274.

Corbin, J., \& Strauss, A. (2015). Basics of qualitative research: Techniques and procedures for developing grounded theory. London: SAGE Publications.

Crawford-Ferre, H.G., \& Wiest, L.R. (2012). Effective online instruction in higher education. The Quarterly Review of Distance Education, 13(1), 11-14.

Devkota, K.R. (2018). Navigating exclusionary-inclusion: School experience of Dalit EFL learners in rural Nepal. Globe: A Journal of Language, Culture and Communication, 6, 115-133. https:// doi.org/10.5278/ojs.globe.v6i0.2331.

Devkota, K.R. (2019). Englishscapes, schooling and difference: Experience of Dalit children in rural Nepal. Unpublished PhD thesis, Tribhuvan University, Nepal.

Dhakal, P., Adhikari, A., \& Rasali, D. (2010). A proposal for an Open University of Nepal for providing higher education to the rural and marginalized people. Himalayan Research Paper Archive. Retrieved 16 January 2021 from: https://digitalrepository.unm.edu/nsc_research/38.

Dumford, A.D., \& Miller, A.L. (2018). Online learning in higher education: exploring advantages and disadvantages for engagement. Journal of Computing in Higher Education, 30, 452-465 https:// doi.org/10.1007/s12528-018-9179-z.

Fillmore, N. (2019). Counting the uncountable: Linguistic diversity in Nepal. Language on the Move, 26 February [blog post]. Retrieved 16 January 2021 from https://www.languageonthemove.com/ counting-the-uncountable-linguistic-diversity-in-nepal/.

Gaskell, A. (2017). Open distance learning. In M.A. Peters (Ed.), Encyclopedia of educational philosophy and theory [online resource]. Singapore: Springer. https://doi.org/10.1007/978-981-287-588-4_100711. 
Gaulee, U. (2014). Higher education in Nepal: Opportunities obscured by internal challenges. In T. Karunakaran, English language teaching in the twenty first century: Issues and Challenges (pp. 10-31). Colombo: Kumaran Book House.

GoN (Government of Nepal) (2016). Act No 3, 2073, approved 2073. 03.30 B.S. [parliamentary act concerning the establishment of Nepal Open University]. Kathmandu: Government of Nepal.

Hennrie, C R., Halverson, L.R., \& Graham, C.R. (2015). Measuring student engagement in technologymediated learning: A review. Computers \& Education, 90, 36-53. https://doi.org/10.1016/j.compe du.2015.09.005.

Hill, C., \& Lawton, W. (2018). Universities, the digital divide and global inequality. Journal of Higher Education Policy and Management, 40(6), 598-610. https://doi.org/10.1080/1360080X.2018.1531211.

Holmes, D R. (1990). Education through radio in Nepal: Changes within and beyond the classroom. Himalaya, 10(2), Art. 9 [Himalayan Research Bulletin, 2-3, 24-29]. https://digitalcommons.macalester.edu/ himalaya/vol10/iss $2 / 9$.

Kim, K.-J., \& Bonk, C.J. (2006). The future of online teaching and learning in higher education. Educause Quarterly, 29(4). 22-30.

Kolbel, A. (2013). (De)valuing higher education: Educated youth, generational differences and a changing educational landscape in Kathmandu, Nepal. Comparative Education, 49(3), 331-343. https://doi. org/10.1080/03050068.2013.803751.

Kozinets, R.V. (2010). Netnography: Doing ethnographic research online. London: SAGE Publications.

Kozinets, R.V. (2015). Netnography: Redefined. London: SAGE Publications.

Kozinets, R.V., Dolbec, P.-Y., \& Earley, A. (2014). Netnographic analysis: Understanding culture through social media data. In U. Flick (Ed.), The SAGE handbook of qualitative data analysis (pp. 262-275). London: SAGE Publications.

Kulavuz-Onal, D. (2015). Using netnography to explore the culture of online language teaching communities. Computer Assisted Language Instruction Consortium (CALCO), 32(3). 426-448. https://doi. org/10.1558/cj.v32i3.26636.

Kulavuz-Onal, D., \& Vasquez, C. (2013). Reconceptualising fieldwork in a netnography of an online community of English language teachers. Ethnography and Education, 8(2), 224-238. https://doi. org/10.1080/17457823.2013.792511.

Madsen, U.A., \& Carney, S. (2011). Education in an age of radical uncertainty: youth and schooling in urban Nepal. Globalization, Societies and Education, 9(1), 115-133. https://doi.org/10.1080/14767 724.2010 .513589 .

Mainali, B.R. (2019). Brain drain and higher education in Nepal. In K. Bista, S. Sharma, \& R.L. Raby (Eds), Higher education in Nepal: Perspectives and policies (pp. 87-99). London: Routledge.

Mbati, LS. (2019). Capabilities-based transformative online learning pedagogy for social justice. In S. Wisdom, L. Leavitt, \& C. Bice (Eds), Handbook of research on social inequality and education (pp. 253272). Hershey, PA: IGI Global.

MoEST (Ministry of Education, Science and Technology) (2017). Educational brochure 2017. Kathmandu: Ministry of Education, Science and Technology, Government of Nepal. Retrieved 16 January 2021 from http://moe.gov.np/assets/uploads/files/Educational_Brochure_2017.pdf.

Morley, L., Leach, F., \& Lugg, R. (2009). Democratising higher education in Ghana and Tanzania: Opportunity structures and social inequalities. International Journal of Educational Development, 29(1), 56-64. https://doi.org/10.1016/j.ijedudev.2008.05.001.

Naidoo, R. (2007). Higher education as a global commodity: The perils and promises for developing countries. Association of Commonwealth Universities. London: Observatory on Borderless Higher Education. Retrieved 16 January 2021 from: http://www.obhe.ac.uk/documents/view_details?id=13.

NPC (National Planning Commission) (2020). The Fifteenth Five-Year Development Plan 2019-2024. Kathmandu: National Planning Commission.

O'Connor, H., \& Madge, C. (2017). Online interviewing. In N.G. Fielding, M R. Lee, \& G. Blank (Eds), The SAGE handbook of online research methods (pp. 416-434). London: SAGE.

Palvia, S., Aeron, P., Gupta, P., Mahapatra, D., Parida, R., Rosner, R., \& Sindhi, S. (2018). Online education: Worldwide status, challenges, trends and implications. Journal of Global Information Technology Management, 21(4), 233-241. https://doi.org/10.1080/1097198X.2018.1542262.

Pangeni, S.K. (2016). Open and distance learning: Cultural practices in Nepal. European Journal of Open, Distance and e-learning, 19(2), 32-45. https://doi.org/10.1515/eurodl-2016-0006.

Pherali, T.J. (2011). Education and conflict in Nepal: Possibilities for reconstruction. Globalisation, Societies and Education, 9(1), 135-154. https://doi.org/10.1080/14767724.2010.513590. 
Radhakrishnan-Nair, K., Aedo, C., Prasad Aryal, M., Maya Sherpa, M., \& Sharma, U. (2020). Nepal steps up remote learning during COVID-19. World Bank Blogs, 17 June [blog post]. Retrieved 14 January 2021 from https://blogs.worldbank.org/endpovertyinsouthasia/nepal-steps-remote-learning-during-covid-19.

Regmi, K D. (2016). World Bank in Nepal's education: Three decades of neoliberal reform. Globalisation, Societies and Education, 15(2), 188-201. https://doi.org/10.1080/14767724.2016.1169517.

Regmi, K.D. (2019). Higher education in Nepal: A handmaiden of neoliberal instrumentalism. Higher Education Policy, n.d. https://doi.org/10.1057/s41307-019-00138-0.

Reid, E., \& Duffy, K. (2018). A netnographic sensibility: Developing the netnographic/social listening boundaries. Journal of Marketing Management, 34(3-4), 263-286. https://doi.org/10.1080/02672 57X.2018.1450282.

Shrestha, N.R. (1997). In the name of development: A reflection on Nepal. Lanham, MD: University Press of America.

Timsina, N.N. (2016). Discourse of higher education reform in Nepal. Unpublished doctoral thesis, Roskilde University, Denmark.

Tomlinson, M. (2017). Student engagement: Towards a critical policy sociology. Higher Education Policy, 30(1), 35-52. https://doi.org/10.1057/s41307-016-0035-3.

UGC (University Grants Commission) (2015). Higher Education Policy 2072. Bhaktapur: University Grants Commission.

UGC (2018). Higher Education Reform Project (HERP): Report on Achievement of Disbursement Linked Indicators. Fifth Report for Disbursement Claim (Year 3-1st Claim, 2017/18) Bhaktapur: University Grants Commission. Retrieved 16 January 2021 from http://www.ugcnepal.edu.np/ugc_header_images/ DLIAchievementReport5Yr3FirstClaimMarch18_Final.pdf.

UIS (UNESCO Institute for Statistics) (2019). Nepal [online database]. Montreal, QC: UNESCO Institute for Statistics. Retrieved 16 January 2021 from http://uis.unesco.org/en/country/np.

UNESCO-IESALC (Instituto Internacional de la UNESCO para la Educación Superior en América Latina y el Caribe). (2020). COVID-19 and higher education: Today and Tomorrow. Caracas: International Institute for Higher Education in Latin America and the Caribbean. Retrieved 16 January 2021 from http://www.iesalc.unesco.org/en/wp-content/uploads/2020/04/COVID-19-EN-090420-2.pdf.

Valentin, K. (2011). Modernity, education and its alternatives: Schooling among the urban poor in Kathmandu. Globalisation, Societies and Education, 9(1), 99-113. https://doi.org/10.1080/14767 724.2010 .513582 .

WHO (World Health Organization) (2020). WHO Director-General's opening remarks at the media briefing on COVID-19 - 11 March 2020. WHO, 11 March [webnews]. Geneva: World Health Organization. Retrieved 16 January 2021 from https:/www.who.int/director-general/speeches/detail/who-directorgeneral-s-opening-remarks-at-the-media-briefing-on-covid-19---11-march-2020.

Witenstein, M.A., \& Palmer, B. (2013). Inequality of participation in Nepalese higher education. Asian Education and Development Studies, 2(2), 162-176. https://doi.org/10.1108/20463161311321439.

Wood, H.B. (1965). The development of education in Nepal. Washington, DC: US Department of Health, Education \& Welfare.

Publisher's Note Springer Nature remains neutral with regard to jurisdictional claims in published maps and institutional affiliations.

Kamal Raj Devkota, PhD, is a lecturer at Tribhuvan University's Research Centre for Educational Innovation and Development (CERID) in Kathmandu, Nepal. He specialises in English education, and earned his doctoral degree for his research on schooling and social difference with particular reference to the participation of Dalit children in English as a Foreign language (EFL) classrooms. He has a wide range of research experience and publications in the field of (language) education policies and pedagogies. He has coordinated a number of research projects, including verification research of Disbursement-Linked Indicators (DLIs) under the School Sector Development Plan (SSDP), for the Nepalese Ministry of Education, Science and Technology (MoEST). 